\title{
Working
}

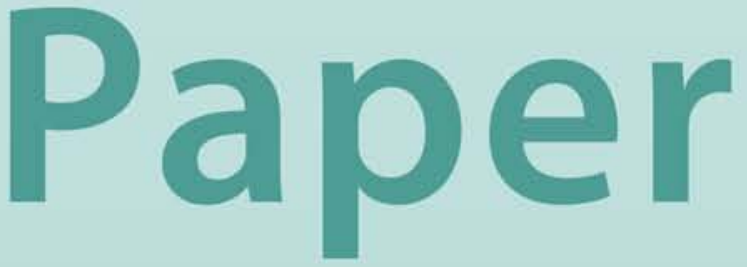




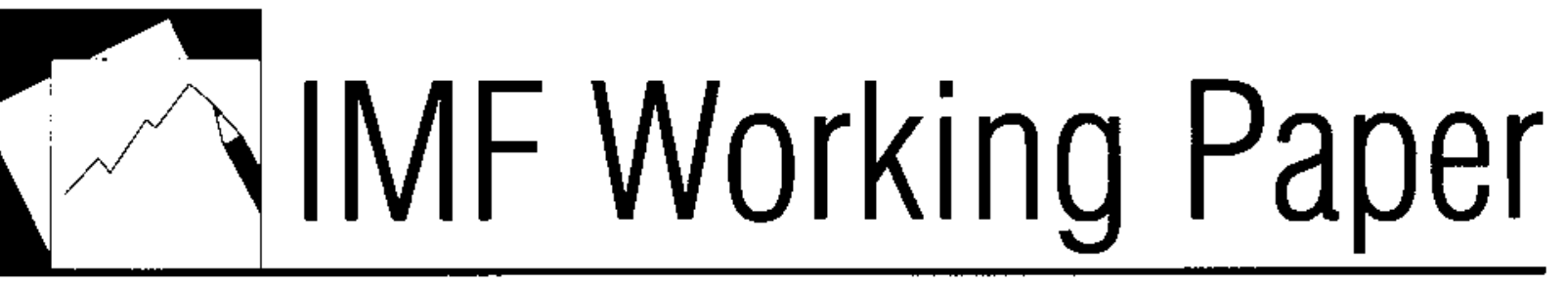

Fiscal Policy and the Current Account

S. M. Ali Abbas, Jacques Bouhga-Hagbe,

Antonio J. Fatás, Paolo Mauro, and Ricardo C. Velloso 


\title{
IMF Working Paper
}

Fiscal Affairs Department

\section{Fiscal Policy and the Current Account}

Prepared by S. M. Ali Abbas, Jacques Bouhga-Hagbe, Antonio J. Fatás, Paolo Mauro, and Ricardo C. Velloso ${ }^{1}$

May 2010

\begin{abstract}
This Working Paper should not be reported as representing the views of the IMF. The views expressed in this Working Paper are those of the author(s) and do not necessarily represent those of the IMF or IMF policy. Working Papers describe research in progress by the author(s) and are published to elicit comments and to further debate.
\end{abstract}

This paper examines the relationship between fiscal policy and the current account, drawing on a larger country sample than in previous studies and using panel regressions, vector autoregressions, and an analysis of large fiscal and external adjustments. On average, a strengthening in the fiscal balance by 1 percentage point of GDP is associated with a current account improvement of $0.2-0.3$ percentage point of GDP. This association is as strong in emerging and low-income countries as it is in advanced economies; and significantly higher when output is above potential.

JEL Classification Numbers:E60, E61, E62, E65, C40, C01

Keywords: fiscal policy, external imbalances, current account, exchange rate Authors' e-mail addresses: sabbas@imf.org, jbouhgahagbe@imf.org, antonio.fatas@insead.edu, pmauro@imf.org, rvelloso@imf.org

\footnotetext{
${ }^{1}$ The authors are grateful to Carlo Cottarelli for suggesting the topic and constructive suggestions, and to Philip Gerson and participants in the workshop on External Imbalances and Public Finances at the European Commission, November 2009 for helpful comments. Abbas, Bouhga-Hagbe, Mauro, and Velloso are in the IMF's Fiscal Affairs Department. Fatás is Professor of Economics at INSEAD.
} 


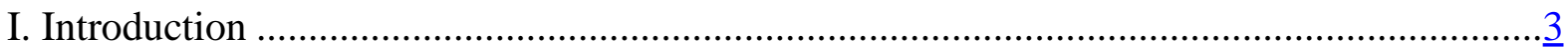

II. Review of Theoretical and Empirical Studies............................................................. 4

III. Large Changes in the Current Account and Fiscal Balances ..........................................

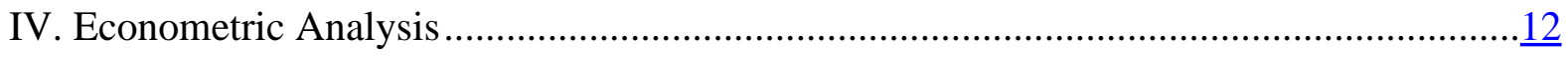

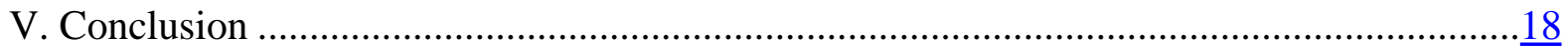

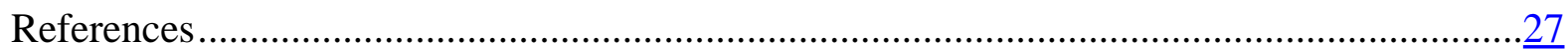

Tables

1. Accounting for Largest Changes in Current Account and Fiscal Balance .........................10

2. Fiscal Policy and the Current Account, Panel Regressions ............................................

Figure

1. Current Account Response to Changes in the Log of Real Government Consumption .......17

Appendices

1. Synthetic Summary of the Empirical Literature ….........................................................19

2. Fiscal Policy, the Current Account and the Real Exchange Rate: A Review of Theory......르 


\section{INTRODUCTION}

The relationship between fiscal policy and the current account has long attracted interest among academic economists and policymakers alike, from various angles. For example, the possible link between fiscal deficits and current account deficits has spurred many studies analyzing the "twin deficit" hypothesis, particularly for the case of the United States. For many countries where current account imbalances are especially large, a relevant question has been to what extent fiscal adjustment can contribute to resolving external imbalances. Going forward, the implications of fiscal stimulus first, and fiscal adjustment later, for current account developments will no doubt continue to generate interest in the context of returning the global economy to strong, sustainable, and balanced growth as the effects of the 2008-9 crisis gradually abate.

This paper analyzes the relationship between fiscal policy and the current account. The paper's main contribution is in the breadth of its empirical investigation, in terms of both country coverage and variety of empirical techniques — whose results are found to complement and corroborate each other. The sample includes more than a hundred countries over a period of more than two decades. The estimates distinguish among advanced, emerging, and low-income countries; more and less open economies; and country-years with small and large output gaps. While the results for oil exporting countries are reported for the sake of completeness, the association between the fiscal balance and the current account for those countries is clearly driven by the impact of oil price changes on both tax revenues and exports simultaneously. The paper thus emphasizes the results for non-oil exporters and subsamples of that group. ${ }^{2}$

To get an informal preview of the data, the paper begins with an identity-based accounting assessment of the extent to which fiscal policy changes underlie large improvements and deteriorations in the current account; and, conversely, the extent to which changes in the current account are correlated with large fiscal expansions and contractions. The paper then turns to more formal analysis, using panel regressions and panel vector auto-regressions (VARs), for the whole range of changes in the variables of interest (including small changes).

The broad findings hold across empirical approaches. Changes in fiscal policy are indeed associated with changes in the current account, but the relationship is far less than one-for-one. Indeed, the analysis of large episodes suggests that, for the most part, the emergence or unwinding of large current account imbalances is not closely associated with fiscal policy changes. Conversely, large fiscal expansions or contractions have rarely displayed a one-for-one association with current account changes. For these large episodes, a mild association is observed between fiscal policy and the current account, primarily for low income countries.

In panel regressions, a strengthening in the fiscal balance by 1 percentage point of GDP is associated with a current account improvement of 0.3 percentage point of GDP. Panel VAR analysis shows an increase in government consumption by 1 percentage point of GDP worsens

\footnotetext{
${ }^{2}$ The paper is primarily concerned with the association between changes in overall fiscal policy and the current account for an individual country. It abstracts from questions about the global transmission of fiscal policy shocks.
} 
the current account by 0.2 percentage point of GDP upon impact, and gradually peters out during the next five years.

The paper is organized as follows. Section II reviews the theoretical and empirical literature. Section III reports the results of the analysis of large changes in the current account and fiscal balance. Section IV reports the findings of the econometric analysis. Section V concludes. An appendix provides further detail on the theoretical literature.

\section{REVIEW OF THEORETICAL AND EMPIRICAL STUDIES}

\section{Basic Identities}

As is well known, fiscal policy and the current account are related through the identity:

$$
C A=\left(S_{p r}-I_{p r}\right)+\left(S_{g}-I_{g}\right)
$$

where $C A$ is the current account, $S_{p r}$ and $I_{p r}$ are private savings and investment, respectively; and $S_{g}$ and $I_{g}$ are government savings and investment. $S_{g}-I_{g}$ is equivalent to the fiscal balance. The same identity holds, and is often used, in terms of shares of GDP. Various theoretical studies have sought to flesh out the mechanisms whereby fiscal policy would affect the terms in the identity above, and to assess the net implications for the current account.

\section{Theoretical Studies}

The major channels through which fiscal policy affects the current account analyzed by theoretical studies include the following. ${ }^{3}$

Direct impact through demand. The most direct way in which fiscal policy can affect the external account is through changes in the government's consumption or investment demand for tradable goods. The government often accounts for a large part of domestic demand, so that, depending on the import propensity, shifts in the government import demand function translate into movements in the trade balance. The result applies more generally, in a Keynesian context, to changes in the fiscal "stance". Thus, a fiscal expansion, whether implemented through a taxreduction or spending increase, will tend to increase demand (including for imports) and the trade deficit, as long as agents are not fully Ricardian.

Impact through the real exchange rate. Fiscal policy can also affect the current account by altering the relative price of nontradables (the real exchange rate): higher government spending on nontradables (such as the services or real estate sectors) can induce a real appreciation, which in turn can tilt private consumption toward, and production away from, tradables. The ensuing

\footnotetext{
${ }^{3}$ The Appendix provides a more detailed summary of the theoretical literature by model classes, emphasizing assumptions relating to, for instance, agent behavior (Ricardian or not), elasticities (of intertemporal vs. intratemporal substitution), size and structure of the economy (small open or large closed) or the exchange rate regime (fixed vs. floating).
} 
worsening in the current account can be prolonged insofar as resource shifts are not easily reversed.

Impact on interest rates and country risk premia. Fiscal tightening can reduce interest rates, including on external debt, thereby improving the current account balance. At the same time, lower risk premia can also increase capital inflows, which can boost demand and real appreciation pressures and eventually worsen the current account (expansionary fiscal contractions). Conversely, fiscal expansions that are deemed unsustainable can generate capital flight and force a rapid external account adjustment (the case of balance of payments crises rooted in fiscal profligacy).

The relative strength of these mechanisms, and thus the net impact of fiscal policy on the current account, is determined by model assumptions. In practice, it will depend of country characteristics. For example, in a small emerging market, the current account impact of a fiscal consolidation may well be adverse if the capital inflow response to a declining risk premium outweighs any direct demand contraction effects. In a large economy, a fiscal expansion may induce a private sector response that often combines a real depreciation (effected, possibly, by firms reducing markups to try and gain market share) and rising consumption demand, so that the impact on the trade balance is difficult to predict. ${ }^{4}$

The importance of country characteristics suggests that, in the empirical analysis, it may be helpful to analyze groups of countries with shared features (e.g., similar levels of economic development).

\section{Empirical Studies}

Previous empirical studies have generally found evidence suggesting that fiscal expansions worsen the current account. Estimates of the impact of 1 percentage point of GDP increase in the government deficit on the current account range between $0.2-0.7$ percentage point of GDP, depending on the sample and techniques used (Appendix 1). A few studies (mostly for large advanced economies) have also addressed the impact of fiscal policy on the real exchange rate, finding mixed effects.

The methodologies used can be broadly grouped into three categories. The first category studies the impact of fiscal policy on external imbalances using causality tests and VARs. The second category analyzes the long-term correlation between indicators of fiscal policy and external imbalances, using cointegration techniques, and single or panel regressions techniques. The third category invokes the narrative approach to identify exogenous changes in fiscal policy and uses regression analysis to study their impact on external imbalances. The rest of this section presents a few key recent studies for each category, with the remaining studies summarized in Table 1.

\footnotetext{
${ }^{4}$ Although some studies have found empirical evidence an association between real depreciations and fiscal expansion in large economies, opinions differ on the underlying reasons. Lane (2010), for instance, emphasizes that that "news that induces the government to provide fiscal impetus may also lead to a sell-off in currency markets."
} 


\section{VAR Studies}

Studies using VARs have primarily looked at small samples of advanced economies. An important methodological choice in this setup is how to identify exogenous fiscal shocks. The preferred method in recent studies (e.g., Monacelli and Perotti, 2007; Beetsma and others, 2007) is to use changes in the log of real government consumption, because this measure is less affected by changes in GDP than is the case for alternatives such as the overall deficit/GDP ratio or the ratio of real government consumption to GDP. Indeed, this measure will also be used in the panel VAR section of this paper.

On the whole, these studies have generally found evidence consistent with a small negative impact of fiscal expansions on the current account balance, except in large economies (like the United States), where the results are more mixed. For selected EU countries, Beetsma and others (2007) find that a government spending innovation of 1 percentage point of GDP worsens the trade balance by 0.5 percentage point of GDP upon impact and by 0.8 after two years. The real effective exchange rate appreciates (after a year), suggesting that the main short-term transmission channel upon impact is output, with the real exchange rate playing a greater role over longer horizons. For the United States, Monacelli and Perotti (2007) find that, following an increase in real government consumption by 1 percentage point of GDP, the trade balance stays around trend initially, but improves by 0.5 percentage points after about 3 years. They find stronger evidence in support of the twin deficits hypothesis (albeit only on impact) in the United Kingdom, Australia, and Canada. Similar results are obtained for the same countries by Corsetti and Muller (2006), who point out that the impact of fiscal shocks on the current account seems to be greater and longer-lasting in economies where total trade is higher as a share of GDP (Canada and the United Kingdom) than in economies where trade is a smaller share of GDP (US and Australia).

\section{Long-term Correlations and Panel Regressions}

Studies involving large panels of countries are relatively rare. They are usually based upon panel regressions and find a statistically significant impact of fiscal variables on external imbalances. Abiad, Leigh, and Mody (2009) study determinants of the current account (in percent of GDP) for 135 countries (over 1975-2004) using a battery of random effects GLS regressions, and report a coefficient of 0.3 on the fiscal balance regressor (in percent of GDP) for the full sample. Mohammadi (2004) finds, for a sample of 20 advanced and 43 emerging and developing economies that a tax-financed spending increase is associated with a current account worsening of 0.16-0.29 percent of GDP (0.23-0.32 percent of GDP for developing countries, and 0-0.26 for advanced economies). If the spending is bond-financed, the current account balance worsens by 0.45-0.72 percent of GDP (0.55-0.81 percent of GDP for developing countries, and 0.22-0.50 for advanced economies). His estimated coefficients imply broadly symmetrical impact for fiscal expansions and contractions.

Other important studies include IMF (2008), which applies panel techniques to both developing and advanced economies and finds that a 1 percentage point of GDP increase in government consumption is associated with an appreciation of the equilibrium real exchange rate of 2.5 to 
3 percent. The actual impact on the current account could vary depending on the dynamic adjustment path of the actual real exchange rate toward the equilibrium; large current account worsenings can obtain if the real exchange rate appreciates above its equilibrium level (overshooting). Khalid and Guan (1999) use cointegration techniques in selected countries and find that the empirical evidence does not support any long-run relationship between the current account deficit and the fiscal deficit for advanced economies, while the data for developing countries does not reject such a relationship. However, their results suggest a causal relationship between the fiscal and current account balances for most countries in their sample, running from the budget balance toward the current account balance.

\section{Narrative Approach}

Romer and Romer (2007) investigate the impact of exogenous changes in the level of taxation on economic activity in the U.S. They use the narrative record, presidential speeches, executivebranch documents, and Congressional reports to identify the size, timing, and principal motivation for all major postwar tax policy actions. This narrative analysis allows them to distinguish tax policy changes resulting from exogenous legislative initiative (aimed, for example, at reducing an inherited budget deficit, or promoting long-run growth) from changes driven by prospective economic conditions, countercyclical actions, and government spending. Their estimates indicate that exogenous tax increases are highly contractionary, largely via a powerful negative effect on investment. Insofar as investment spending is an important current account determinant, the results point to a strong association between fiscal contraction and current account improvements. Using Romer-Romer data, Feyrer and Shambaugh (2009) estimate that one dollar of unexpected tax cuts in the U.S. worsens the U.S. current account deficit by 47 cents.

\section{LARge Changes in the CurRent Account AND Fiscal BalanCES}

We begin our empirical analysis by studying how the emergence, or resolution, of large external imbalances has been associated with fiscal policy changes; and, conversely, how often large fiscal contractions and expansions have been associated with sizable current account improvements or worsenings. To this end, we apply the well-known identity (1) to 176 countries, divided into 46 oil exporters and 140 non-oil exporters, the latter subdivided into advanced, emerging and developing economies. The sample period spans 1980-2007 for most countries. ${ }^{5}$ For each subsample of countries, we consider the 50 largest (cumulative) increases in the relevant variable (current account or fiscal balance, in percentage points of GDP) over one-, three- and seven-year horizons, and repeat the exercise for the 50 largest deteriorations (Table 1).

\footnotetext{
${ }^{5}$ The data for these exercises are drawn from the IMF's World Economic Outlook database, which facilitates checking that the identity above holds. Moreover, data quality has been checked through reconciliation of WEO data with IMF staff reports. For some advanced economies, the data series start in the 1950s; for some transition economies, the data are available for the post-1990 period only.
} 
It is important to note upfront that the accounting exercises presented in this section cannot be given a causal interpretation. For instance, improvements in both the fiscal and current account balances could reflect binding financing constraints on the government in the aftermath of a sudden stop in capital inflows. Favorable terms of trade changes would cause both balances to improve. And strong aggregate demand growth would boost both fiscal revenues and the demand for imports, thus leading to opposite changes in the fiscal and current account balances (as witnessed, for example, in a number of Eastern European economies in the early to mid-2000s).

\section{Large Current Account Improvements and Deteriorations}

In the non-oil-exporting advanced economies, the 50 largest current account improvements (averaging 4-7 percentage points of GDP, depending on the horizon considered) were not associated with changes in the fiscal balance at the one- or three-year horizons, though they were associated with fiscal balance strengthening at the seven-year horizon. The largest current account improvements at the seven-year horizon were experienced by smaller advanced European economies. These improvements were often sizable, to the tune of 10 percentage points of GDP, with the contemporaneous consolidations averaging 4 percentage points of GDP. Large current account deteriorations were associated with changes in the private sector savingsinvestment balance rather than the fiscal stance, which on average remained neutral. A positive association between the current account and the fiscal balance was partly masked by rapid, domestic-demand based economic growth, which in several episodes in advanced European economies in recent years resulted in both large current account worsenings and fiscal balance improvements.

For the non-oil-exporting emerging market economies, the largest current account improvements (averaging 6-10 percentage points of GDP) were mirrored in greater net private sector savings, with fiscal balances unchanged or even moving in the opposite direction. Several of the largest improvements occurred in the context of large real depreciations and V-shaped economic growth recoveries in the aftermath of the Asian financial crisis (e.g., Korea, the Philippines, and Thailand). Similarly, the largest current account deteriorations (with many episodes in Central and Eastern European economies) were associated with net private sector dissaving rather than changes in fiscal balances. A comparison of these post-1990 episodes with pre-1990 ones suggests that the absolute size of current account changes has increased markedly over time, while the traditional association between fiscal policy and the real exchange rate has broken down, perhaps due to the growing importance of financial capital flows in the determination of relative prices.

In the non-oil-exporting developing countries, the largest current account improvements averaged above 10 percentage points of GDP, and were accompanied by both fiscal consolidation (around 4 percentage points of GDP) and relative price changes (real depreciations). More than half of the episodes overlapped with IMF-supported programs. Conversely, large current account deteriorations were associated with substantial fiscal balance worsenings. The list of episodes is dominated by sub-Saharan Africa and the Caribbean, but some Central and Eastern European economies, such as Albania and Moldova, also show up. Most of these cases coincide with private saving declines, rising government capital spending, and real appreciations. 
The composition of fiscal adjustments associated with large current account improvements was also studied. Using a subset of the latter where the response ratio exceeded 0.5 , it was found that fiscal adjustments become noticeably skewed towards spending reductions as the horizon lengthens from 1 to 7 years. This result also generally extends to emerging and advanced nonoil-exporting economies, but not to oil exporters, where fiscal balance improvements remain revenue-led at all horizons.

Oil exporters experienced the largest current account improvements in the sample, with the top 50 episodes averaging between 15-28 percentage points of GDP (depending on the length of the horizon). On average, one third to one half of these improvements was accounted for by greater government savings. In almost all cases, improvements in both the current account and the fiscal balance resulted from increases in oil prices. The episodes are dominated by oil producers in the Middle East and Central Asia (two fifths) and Africa (one third), and occurred, for the most part, in the context of the sharp oil price surge through 2008. With the proceeds of these oil booms largely saved and reinvested abroad, real appreciation was limited. The largest current account deteriorations in the sample were somewhat smaller; one fourth to one third of such worsenings was accounted for by deteriorating fiscal balances-again, reflecting the adverse impact of oil price declines on both oil exports and oil revenues.

\section{Large Fiscal Contractions and Expansions}

In the converse exercise, we identify large changes in the fiscal balance, and study the behavior of the current account during those episodes. For each episode, we compute the "response ratio" as the percentage point change in the current account balance/GDP ratio associated with a one percentage point increase in the fiscal balance/GDP ratio. The reported ratio for each country group is the median calculated over the 50 top episodes for that group. Again, these accounting exercises should not be given a causal interpretation - this is highlighted by considerably faster economic growth and more favorable terms of trade changes during fiscal contractions than fiscal expansions, pointing to the important impact of economic growth and terms of trade changes on the fiscal balance (as well as on the current account). 
Table 1. Accounting for Largest Changes in Current Account and Fiscal Balance (In percent of GDP, means)

\begin{tabular}{|c|c|c|c|c|c|c|c|c|c|}
\hline & & & & Private & & & Government & & \\
\hline Country Group & $\begin{array}{c}\text { Horizon } \\
\text { (years) }\end{array}$ & $\begin{array}{l}\text { Current } \\
\text { Account }\end{array}$ & Saving & Investment & $\begin{array}{c}\text { S-I } \\
\text { Balance }\end{array}$ & Saving & Investment & $\begin{array}{c}\text { S-I } \\
\text { balance }\end{array}$ & $\begin{array}{l}\Delta \text { Current Account/ } \\
\Delta \text { Fiscal Balance }\end{array}$ \\
\hline \multicolumn{9}{|c|}{ Period Increase (in percentage points of GDP) } & Median Ratio \\
\hline \multicolumn{10}{|c|}{ TOP 50 CURRENT ACCOUNT IMPROVEMENTS } \\
\hline \multirow{3}{*}{ Advanced } & 1 & 3.2 & 1.3 & -1.6 & 3.0 & -0.1 & -0.2 & 0.1 & \\
\hline & 3 & 5.0 & 2.0 & -2.5 & 4.5 & 0.0 & -0.4 & 0.4 & \\
\hline & 7 & 6.6 & 0.6 & -2.8 & 3.4 & 2.3 & -0.8 & 3.2 & \\
\hline \multirow{3}{*}{ Emerging } & 1 & 5.7 & 2.8 & -2.8 & 5.6 & -0.3 & -0.3 & 0.0 & \\
\hline & 3 & 7.9 & 5.2 & -2.9 & 8.0 & -0.4 & -0.3 & -0.2 & \\
\hline & 7 & 9.9 & 5.0 & -4.5 & 8.9 & 0.3 & -0.3 & 0.4 & \\
\hline \multirow{3}{*}{ Low-income } & 1 & 10.8 & 6.8 & -1.8 & 8.5 & 0.7 & -1.4 & 2.1 & \\
\hline & 3 & 13.2 & 7.1 & -1.8 & 9.0 & 1.9 & -2.5 & 4.2 & \\
\hline & 7 & 11.8 & 7.5 & 0.0 & 7.3 & 2.7 & -1.7 & 4.5 & \\
\hline \multicolumn{10}{|c|}{ TOP 50 CURRENT ACCOUNT DETERIORATIONS } \\
\hline \multirow{3}{*}{ Advanced } & 1 & -3.7 & -2.1 & 1.7 & -3.8 & 0.3 & 0.1 & 0.2 & \\
\hline & 3 & -6.2 & -4.2 & 2.9 & -7.1 & 1.2 & 0.3 & 0.9 & \\
\hline & 7 & -6.5 & -5.2 & 2.2 & -7.5 & 1.4 & 0.4 & 1.0 & \\
\hline \multirow{3}{*}{ Emerging } & 1 & -5.6 & -3.4 & 2.4 & -5.8 & 0.1 & -0.1 & 0.2 & \\
\hline & 3 & -9.1 & -5.7 & 4.3 & -10.0 & 0.8 & -0.1 & 0.9 & \\
\hline & 7 & -6.4 & -3.5 & 3.6 & -7.1 & 0.5 & -0.2 & 0.7 & \\
\hline \multirow{3}{*}{ Low-income } & 1 & -10.7 & -5.4 & 3.1 & -8.5 & -0.6 & 1.6 & -2.2 & \\
\hline & 3 & -13.3 & -6.2 & 4.4 & -10.9 & -0.5 & 2.2 & -2.7 & \\
\hline & 7 & -12.2 & -0.5 & 4.7 & -5.1 & 0.8 & 7.6 & -6.8 & \\
\hline \multicolumn{10}{|c|}{ TOP 50 FISCAL BALANCE IMPROVEMENTS } \\
\hline \multirow{3}{*}{ Advanced } & 1 & 0.2 & -2.0 & 0.6 & -2.6 & 2.6 & -0.2 & 2.8 & 0.1 \\
\hline & 3 & -0.4 & -2.4 & 1.2 & -3.6 & 3.2 & -0.1 & 3.2 & -0.3 \\
\hline & 7 & 2.0 & -4.4 & 1.6 & -6.0 & 7.5 & -0.6 & 8.1 & 0.2 \\
\hline \multirow{3}{*}{ Emerging } & 1 & 0.4 & -2.5 & 1.0 & -3.5 & 2.8 & -1.1 & 3.8 & 0.1 \\
\hline & 3 & 0.2 & -3.7 & 2.2 & -6.0 & 4.7 & -1.2 & 6.0 & 0.1 \\
\hline & 7 & 1.3 & -2.8 & 3.1 & -5.8 & 5.4 & -1.7 & 7.0 & 0.1 \\
\hline \multirow{3}{*}{ Low-income } & 1 & 1.2 & -6.4 & 1.9 & -8.3 & 6.1 & -3.6 & 9.6 & 0.1 \\
\hline & 3 & 4.2 & -6.8 & 0.5 & -7.3 & 9.0 & -2.8 & 11.6 & 0.5 \\
\hline & 7 & 4.8 & -2.9 & 3.8 & -6.8 & 8.6 & -2.8 & 11.6 & 0.4 \\
\hline \multicolumn{10}{|c|}{ TOP 50 FISCAL BALANCE DETERIORATIONS } \\
\hline \multirow{3}{*}{ Advanced } & 1 & 0.3 & 1.7 & -1.4 & 3.1 & -2.9 & 0.1 & -2.9 & 0.0 \\
\hline & 3 & -0.2 & 2.7 & -2.8 & 5.5 & -5.6 & 0.2 & -5.8 & 0.0 \\
\hline & 7 & -1.0 & 2.0 & -3.4 & 5.4 & -6.4 & 0.1 & -6.5 & 0.1 \\
\hline \multirow{3}{*}{ Emerging } & 1 & 0.4 & 2.6 & -1.4 & 3.9 & -2.7 & 0.8 & -3.5 & 0.0 \\
\hline & 3 & -0.2 & 2.7 & -1.7 & 4.4 & -3.9 & 0.8 & -4.7 & -0.1 \\
\hline & 7 & 1.8 & 3.5 & -3.7 & 6.7 & -4.5 & 0.7 & -5.3 & -0.2 \\
\hline \multirow{3}{*}{ Low-income } & 1 & -2.4 & 7.2 & -0.6 & 7.5 & -6.3 & 3.6 & -9.9 & 0.1 \\
\hline & 3 & -5.2 & 8.3 & 0.2 & 7.6 & -7.9 & 4.3 & -12.6 & 0.3 \\
\hline & 7 & -2.6 & 9.6 & 1.1 & 7.5 & -7.3 & 2.2 & -10.0 & 0.2 \\
\hline
\end{tabular}

Source: IMF, World Economic Outlook database. 
In the non-oil-exporting advanced economies, large fiscal contractions are not associated, on average, with changes in the current account. ${ }^{6}$ There is significant variation, however: mediumterm response ratios of about 0.4 are observed for several episodes in advanced European economies in the mid-to-late 1990s and early 2000s. In contrast, some growth-induced fiscal contraction episodes are associated with current account worsenings, the latter most likely resulting from the contemporaneous rapid domestic demand growth. For fiscal expansions, the association is also essentially zero on average, and the response ratio is only 0.3 even for the well-known "twin deficits" of the late 1980s and 2000s for the United States.

For non-oil-exporting emerging markets, again the average association of fiscal contractions with the current account is close to zero, with wide variation across different episodes. Response ratios above 0.5 are observed for several, sustained fiscal tightening episodes in the 2000s (e.g., Brazil, Chile, China, Lebanon, Pakistan and Peru). However, for many other episodes in East Asia during the mid-1990s and emerging Europe more recently, response ratios were zero or the current account worsened despite the fiscal contraction. In those cases, fiscal tightening may have attracted capital inflows to prompt real appreciations that ultimately worsened the current account. For fiscal expansions, the average response ratio is slightly negative. In some episodes, fiscal deteriorations are accompanied by real appreciations and response ratios as high as 0.5 (e.g., Jordan in 2005-07; Lebanon in the mid-1990s; Sri Lanka). However, in even more episodes, fiscal deficits increased as a result of output declines, particularly in the late 1990s/early 2000s for the countries affected by the East Asian and Russian crises. In these cases, large crisis-induced real depreciations helped improve the current account.

For non-oil-exporting developing countries, large fiscal contractions were associated with significant improvements in the current account balance, with response ratios exceeding 1 in a wide range of countries in different continents. Higher response ratios in developing countries may partly reflect: large foreign aid inflows for budget support; the relatively high importance of the public sector in the economy, as well as the high import content of government capital spending; openness to trade; sustained participation in IMF stabilization programs; and relative immunity to capital inflow-induced real appreciations. Large fiscal expansions were associated with substantial current account worsenings. In many cases, fiscal expansions consisted largely of increases in capital spending, but compensating export returns from such investments seemed insufficient, even at longer horizons.

For oil exporters, most fiscal expansions can be traced to the period of low world oil prices in the 1990s. However, even during the recent oil price boom, some oil exporters registered large and expanding twin deficits—notably, Nigeria, Sudan and Yemen (through 2007) —as a result of spending pressures, erosion of the non-oil tax base, and greater demand for subsidized petroleum products. Large fiscal contractions were predictably associated with terms-of-trade induced current account improvements.

\footnotetext{
${ }^{6}$ The median response ratio is slightly higher ( 0.2 for fiscal contractions) when using structural fiscal balances (scaled to potential GDP), reliable time series of which are only available for advanced economies.
} 
The foregoing suggests that the association between current account balances and fiscal balances was, on average, nil for the non-oil-producing advanced economies and emerging markets in the sample; positive and sizable for the non-oil-producing developing countries; and strongly positive only in the oil-producing countries, where simultaneous improvements (worsenings) in both oil exports and oil revenues largely reflected increases (decreases) in world oil prices.

\section{ECONOMETRIC ANALYSIS}

Turning to econometric analysis, this section analyzes the empirical relationship between fiscal policies and the current account, using panel regressions and panel VARs for 124 countries over 1985-2007. The analysis distinguishes between advanced, emerging and low-income countries; between oil exporters and non-oil exporters; between more open and less open economies; and between country-years with large output gaps and those where the gap was smaller. The data for this section are drawn from the World Bank's World Development Indicators (except for financial openness, drawn from Lane and Milesi-Ferretti, 2006). The main advantage of this data set is that for real output at purchasing-power-parity and its subcomponents (including real government consumption, a key variable in this section) it has longer coverage and strong international consistency: it is essentially the same as the well know Summers-Heston data set, with even greater coverage for developing economies.

The findings suggest that fiscal policy, as measured by the fiscal balance/GDP ratio or the log of real government consumption, is significantly associated with the current account. On average, a strengthening in the fiscal balance by 1 percentage point of GDP is associated with a current account improvement by 0.3 percentage points of GDP. The impact varies depending on country characteristics, as explained below.

\section{Panel Regressions}

A battery of panel regressions (with individual country fixed effects) using annual data suggests a positive, significant, and robust association between fiscal balances and current account balances (Table 2). ${ }^{7}$ The coefficient on the fiscal balance-to-GDP ratio in simple fixed effects regressions of the current account-to-GDP ratio is 0.38 , but the coefficient weakens to 0.28 when oil-exporting economies are excluded. This is intuitive given that oil price shocks typically induce large comovements in public sector balances (through oil revenues) and the current account (through oil exports) in oil exporting countries. Indeed, the results reported in the remainder of this section relate to sub-samples that exclude oil exporters as well as financial centers (countries whose ratio of financial assets plus liabilities exceeds 150 percent of GDP). The results are robust to controlling for GDP per capita, financial openness, and trade openness.

The estimated impact of fiscal policy on the current account is somewhat stronger in emerging and developing economies ( 0.31 percentage points of GDP) than it is for advanced economies (0.24), though the difference is not significantly different. A possible interpretation is that, in

\footnotetext{
7 The results presented in this section hold using panels based on 5-year averages (except that the exercise was not conducted for the exercise involving differences in the output gap).
} 
emerging and developing economies, public spending tends to include the purchase of foreignmade investment goods, and is thus more likely to spill over into imports than is the case in advanced economies.

The association between fiscal policy and the current account is significantly affected by the level of the output gap (defined as actual output less potential output, with potential output estimated using the Hodrick-Prescott filter). Focusing on the sample of countries where it was possible to obtain a meaningful measure of the output gap (i.e., countries with more than 20 years of data), and letting the impact of a change in the fiscal balance on the current account differ depending on whether country-years were characterized by above- or belowpotential output, the estimated coefficient is higher (0.46) in country-years where output is above potential than it is $(0.26)$ in country-years where output is below potential. The difference in the slope coefficient is significant at the 1 percent level. ${ }^{8}$ A possible interpretation of this result is as follows: when output is above its potential, a fiscal expansion is more likely to result in additional imports; instead, when output is below potential, the additional demand stemming from a fiscal expansion is more likely to be met by increased production of domestic goods and services, rather than through imports. ${ }^{9}$ An alternative explanation could lie in the behavior of private consumption, which typically collapses much more than government consumption, thus driving an improving current account, while fiscal balances deteriorate.

Finally, splitting the sample between economies that are above and below the median with respect to openness to international trade, the relationship between fiscal policy and the current account is significantly stronger in economies that are more open to international trade (with a slope coefficient of 0.32 ) than in less open economies (0.22). The difference is statistically significant at the 1 percent level. In economies more open to international trade, it is natural for a greater share of the additional demand stemming from a fiscal expansion to be met through imports.

\footnotetext{
${ }^{8}$ This result is robust to restricting the sample to the advanced economies only, for which measures of the output gap are generally considered to be more reliable.

${ }^{9}$ An alternative interpretation could be in times of economic crisis, private consumption collapses much more than government consumption, which translates into a stronger current account, while the fiscal balances deteriorate.
} 
Table 2. Fiscal Policy and the Current Account, Panel Regressions

\begin{tabular}{|c|c|c|c|c|c|c|c|}
\hline & $\begin{array}{l}\text { Regression I } \\
\text { (Full sample) }\end{array}$ & $\begin{array}{l}\text { Regression II } \\
\text { (Excl. oil } \\
\text { exporters) }\end{array}$ & $\begin{array}{l}\text { Regression III } \\
\text { (Excl. oil } \\
\text { exporters and } \\
\text { excl. } \\
\text { fopen } \geq 150) 1 / \\
\end{array}$ & $\begin{array}{l}\text { Regression IV } \\
\text { (Excl. oil } \\
\text { exporters and } \\
\text { excl. } \\
\text { fopen } \geq 150) 1 / \\
\end{array}$ & $\begin{array}{c}\text { Regression V } \\
\text { (Excl. oil } \\
\text { exporters and } \\
\text { excl. fopen } \geq 150 \text { ) } \\
1 / 21 \\
\end{array}$ & $\begin{array}{c}\text { Regression VI } \\
\text { (Excl. oil } \\
\text { exporters and } \\
\text { excl. fopen } \geq 150 \text { ) } \\
1 / 21 \\
\end{array}$ & $\begin{array}{c}\text { Regression VII } \\
\text { (Excl. oil } \\
\text { exporters and } \\
\text { excl. fopen } \geq 150 \text { ) } \\
1 / 2 / \\
\end{array}$ \\
\hline \multicolumn{8}{|l|}{$\begin{array}{l}\text { Dependent variable } \\
\text { (current account in percent of GDP) }\end{array}$} \\
\hline \multirow[t]{2}{*}{ Government balance in percent of GDP } & 0.38 & 0.28 & 0.28 & & 0.25 & & \\
\hline & $(0.02)$ & $(0.02)$ & $(0.02)$ & & $(0.02)$ & & \\
\hline \multirow{2}{*}{$\begin{array}{l}\text { Government balance in percent of GDP } \\
\text { (advanced countries) }\end{array}$} & & & & 0.24 & & & \\
\hline & & & & $(0.04)$ & & & \\
\hline \multirow{2}{*}{$\begin{array}{l}\text { Government balance in percent of GDP } \\
\text { (emerging and developing countries) }\end{array}$} & & & & 0.31 & & & \\
\hline & & & & $(0.03)$ & & & \\
\hline \multirow{2}{*}{$\begin{array}{l}\text { Government balance in percent of GDP (years } \\
\text { with output below potential) }\end{array}$} & & & & & & 0.19 & \\
\hline & & & & & & (0.03) & \\
\hline \multirow{2}{*}{$\begin{array}{l}\text { Government balance in percent of GDP (years } \\
\text { with output above potential) }\end{array}$} & & & & & & 0.37 & \\
\hline & & & & & & $(0.03)$ & \\
\hline \multirow{2}{*}{$\begin{array}{l}\text { Government balance in percent of GDP } \\
\text { (countries with more trade openness) }\end{array}$} & & & & & & & 0.32 \\
\hline & & & & & & & $(0.03)$ \\
\hline \multirow{2}{*}{$\begin{array}{l}\text { Government balance in percent of GDP } \\
\text { (countries with less trade openness) }\end{array}$} & & & & & & & 0.22 \\
\hline & & & & & & & $(0.04)$ \\
\hline \multirow[t]{2}{*}{ Real GDP per capita (divided by 1000, US $\$$ ) } & 0.13 & 0.06 & 0.05 & 0.06 & 0.10 & 0.09 & 0.05 \\
\hline & $(0.05)$ & $(0.05)$ & $(0.05)$ & $(0.05)$ & $(0.05)$ & $(0.05)$ & $(0.05)$ \\
\hline \multirow{2}{*}{$\begin{array}{l}\text { Trade Openness } \\
\text { ("Exports + Imports" over GDP) }\end{array}$} & 0.01 & 0.00 & 0.00 & 0.00 & 0.00 & 0.00 & 0.00 \\
\hline & $(0.003)$ & $(0.003)$ & $(0.003)$ & $(0.003)$ & $(0.003)$ & $(0.003)$ & $(0.003)$ \\
\hline \multirow{2}{*}{$\begin{array}{l}\text { Financial openness ("Financial } \\
\text { assets+Financial liabilities" over GDP) }\end{array}$} & 0.00 & 0.00 & 0.00 & 0.00 & 0.00 & 0.00 & -0.01 \\
\hline & $(0.000)$ & $(0.000)$ & $(0.02)$ & $(0.02)$ & $(0.02)$ & $(0.02)$ & $(0.02)$ \\
\hline Number of Observations & 2579 & 2002 & 1978 & 1978 & 1876 & 1876 & 1978 \\
\hline Number of Countries & 124 & 95 & 95 & 95 & 87 & 87 & 95 \\
\hline \multicolumn{8}{|l|}{ R-squared } \\
\hline within & 0.12 & 0.07 & 0.07 & 0.08 & 0.06 & 0.08 & 0.08 \\
\hline between & 0.21 & 0.26 & 0.22 & 0.29 & 0.31 & 0.27 & 0.17 \\
\hline overall & 0.22 & 0.16 & 0.14 & 0.17 & 0.18 & 0.17 & 0.13 \\
\hline
\end{tabular}

Data Source: World Bank's World Development Indicators

Notes: All regressions include country fixed effects. Standard errors in parentheses.

$1 /$ "fopen" is "financial assets+financial liabilities" over GDP. This regression only considers observations where fopen is less than 150 percent of GDP.

$2 /$ Excludes countries for which the output gap cannot be meaningfully computed (i.e. countries with less than 20 years of observations for real GDP). 


\section{Panel Vector Auto-regressions (VARs)}

To analyze the dynamic impact of fiscal policy changes on the current account, this section moves to a VAR specification. Following previous studies, fiscal policy changes are proxied by changes in the logarithm of real government consumption (denoted by lrgovcons), which behaves less endogenously in the face of output shocks than the government spending-to-GDP ratio or, a fortiori, the fiscal balance-to-GDP ratio. The key variable of interest remains the current account-to-GDP ratio (cagdp). Output shocks are controlled for by including the log of real GDP (Irgdp) in the system. The specification is similar to the one used by Monacelli and Perotti (2007), except that the present paper runs panel VARs, removing individual country fixed effects through the Helmert transformation. ${ }^{10}$

This paper's identification and ordering scheme follows that employed in Beetsma and others (2007). Specifically, letting $Z_{t}$ denote a vector containing the variables described above, the following structural model is estimated:

$$
A_{0} Z_{t}=A_{1} Z_{t-1}+A_{2} Z_{t-2}+\varepsilon_{t}
$$

where $\varepsilon_{t}$ is a vector of mutually uncorrelated innovations and the $A_{i}$ are coefficient matrices. ${ }^{11}$ We employ two specifications: a preferred specification, (i) $Z_{t}=[\operatorname{lrgovcons}, \operatorname{lrgdp} \text {, cagdp }]^{\prime}$; and an alternative specification, (ii) $Z_{t}=[\text { Irgovcons, cagdp, } \operatorname{lrg} d p]^{\prime}$. In both specifications, government consumption is the "first" variable in $Z_{t}$. This implies that government spending responds to the other variables with a delay of one year, whereas the model ignores within-year responses of government consumption to output and the current account. In practice, government consumption can respond to output developments within the year as evidenced by the adoption of revised budgets during fiscal years. Nonetheless, such revisions are not frequent and the bulk of government consumption is usually determined before the new fiscal year starts. In the preferred specification, the current account is assumed to respond not only to government spending but also to output during the year, whereas output responds to government spending during the year but to the current account only with a lag of a year. In the alternative specification, output responds within the year to both government spending and the current account, whereas the current account is assumed to respond to government spending within the year, but to output only with a delay of one year. For the sake of brevity, only results from the preferred specification are reported, but those obtained using the alternative specification are

\footnotetext{
${ }^{10}$ The standard mean-differencing method to remove fixed effects would bias coefficient because of the correlation between lagged dependent variable regressors and fixed effects, The Helmert transformation avoids this problem by using forward mean-differencing (Arellano and Bond, 2005).

${ }^{11}$ The coefficients matrix $A_{0}$ reflects contemporaneous relationships among the variables in $Z_{t}$. It is not possible to estimate $A_{0}$ and therefore identify the innovations $\varepsilon_{t}$ without further assumptions. Therefore, we assume that $A_{0}$ is a lower triangular matrix.
} 
essentially the same. Results are presented in the form of the dynamic impulse response of the current account to an increase in the log of real government consumption equivalent to the sample standard deviation. Impulse responses are within a band representing a 90 percent confidence interval estimated using Monte Carlo simulations (with 500 iterations).

The empirical findings suggest that a fiscal expansion (proxied here by an increase in government consumption) generally leads to a worsening in the current account balance, though the duration of the impact depends on the country sample (see below). ${ }^{12}$

- $\quad$ Figure 1 (top left-hand side panel) shows the evolution of the current account-to-GDP ratio following an increase in the log of real government consumption by one standard deviation (equivalent to an increase in the government spending-to-GDP ratio by 1.35 percentage points-by comparison, the average ratio in the sample is 17 percent). The effect upon impact is significant: during the year of the spending shock, for the full sample the results imply a deterioration in the current account by 0.35 percentage point of GDP. With oil exporters excluded from the sample (top right-hand side panel), the implied coefficient is smaller, as expected, at 0.28 percentage point of GDP. Equivalently, a standardized government consumption increase by 1 percentage point of GDP would worsen the current account balance by 0.26 percentage point of GDP during the year of the shock in the full sample and 0.20 percentage point of GDP in the sample without oil exporters. The magnitude of the impact is thus similar to that obtained from the panel regressions. The degree of persistence of the impact differs across samples, however: for the full sample, the impact is somewhat smaller but still (marginally) significant after six years; excluding the oil exporters, the impact is no longer significantly different from zero after a couple of years and is estimated to be very small after five or six years.

- $\quad$ The current account response to government consumption shocks for emerging and lowincome countries is presented in Figure 1, bottom left-hand side panel. Following an increase in the log of real government consumption by one standard deviation (equivalent to an increase in the government spending-to-GDP ratio by 1.39 percentage points-by comparison, the average ratio in the sample is 15 percent), the current account worsens by 0.36 percentage point of GDP upon impact and 0.53 percentage point of GDP after one year. Equivalently, in response to a 1 percentage point of GDP increase in government consumption, the current account worsens by 0.26 percentage point of GDP during the year of the shock and 0.38 percentage point of GDP one year after the shock. The current account response remains significant after five or six years for the sample including oil exporters. Excluding the oil exporters (bottom right-hand side panel), an increase in the log of real government consumption by one standard deviation (equivalent to an increase in the government spending-to-GDP ratio by 1.42 percentage points-by comparison, the average ratio in the sample is 15 percent), leads the current account to worsen by 0.29 percentage point of GDP upon impact and 0.34 percentage point of GDP after one year. Equivalently, in response to a 1 percentage point of GDP increase in government

\footnotetext{
${ }^{12}$ All samples in this section exclude economies where the sum of financial assets plus liabilities exceeds 150 percent of GDP.
} 
consumption, the current account worsens by 0.20 percentage point of GDP during the year of the shock and 0.24 percentage point of GDP one year after the shock. The impact gradually peters out and becomes insignificant after four years for the sample that excludes the oil exporters. The somewhat stronger response in a sample consisting of emerging and low-income countries only, compared with the full sample, is consistent with the view that the import content of government consumption is higher, and the relative price channel more important, in emerging and developing countries than is the case for advanced economies.

Figure 1. Current Account Response to Changes in the Log of Real Government Consumption

Full Sample

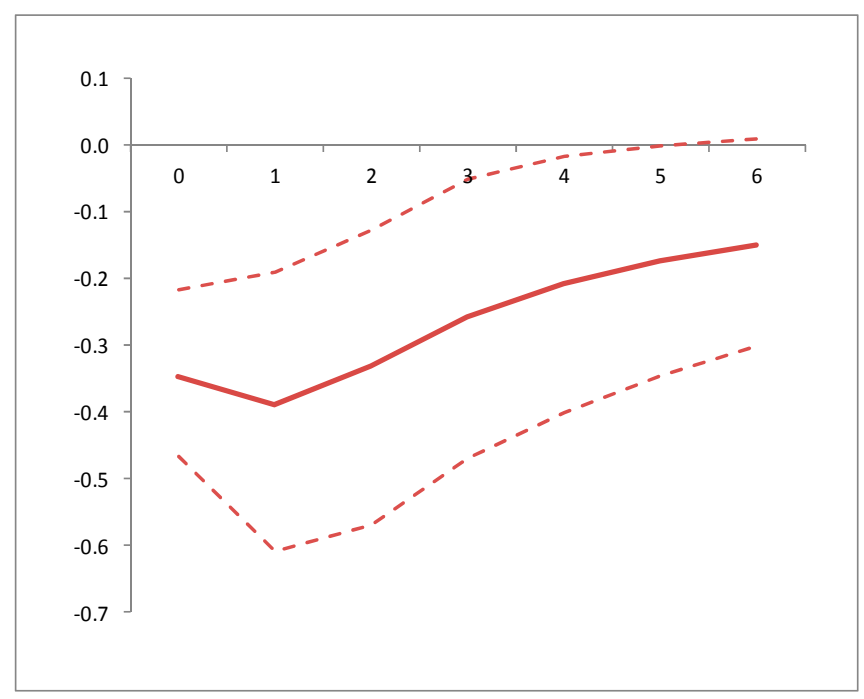

Emerging and Low-Income Countries

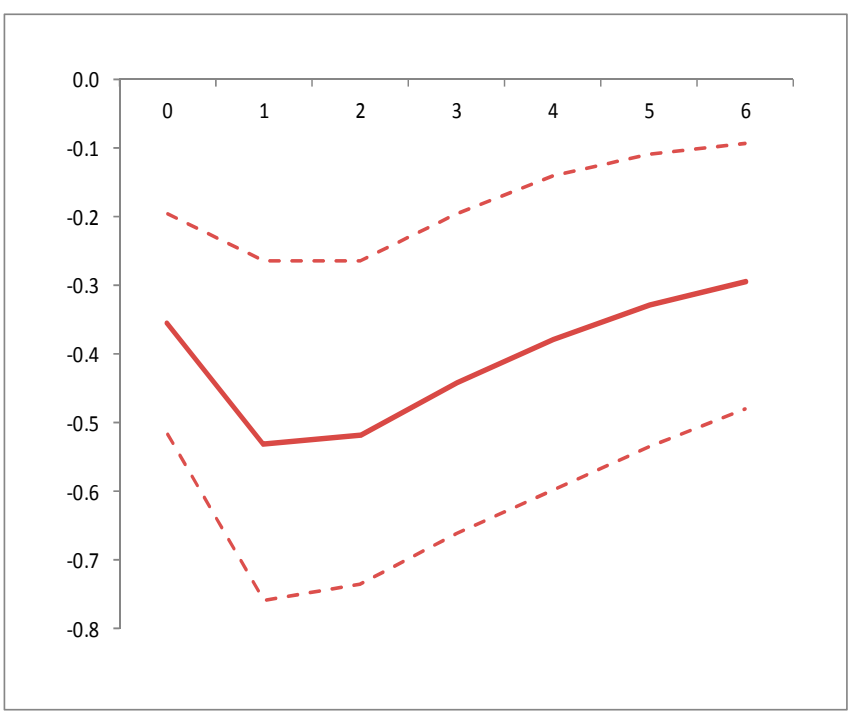

Excluding Oil Exporters

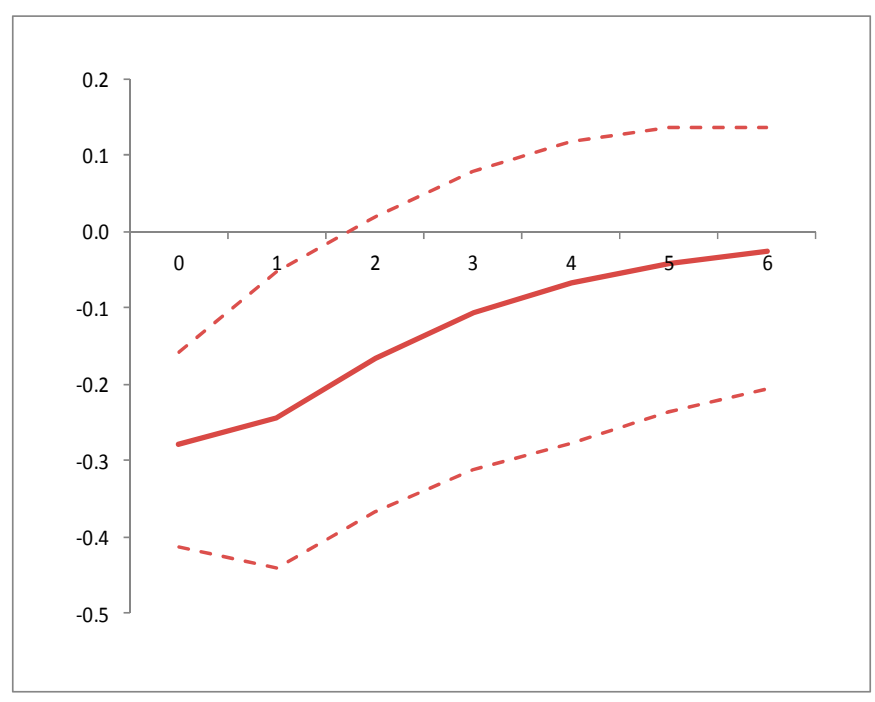

Emerging and Low-Income Countries (Excl. oil exp.)

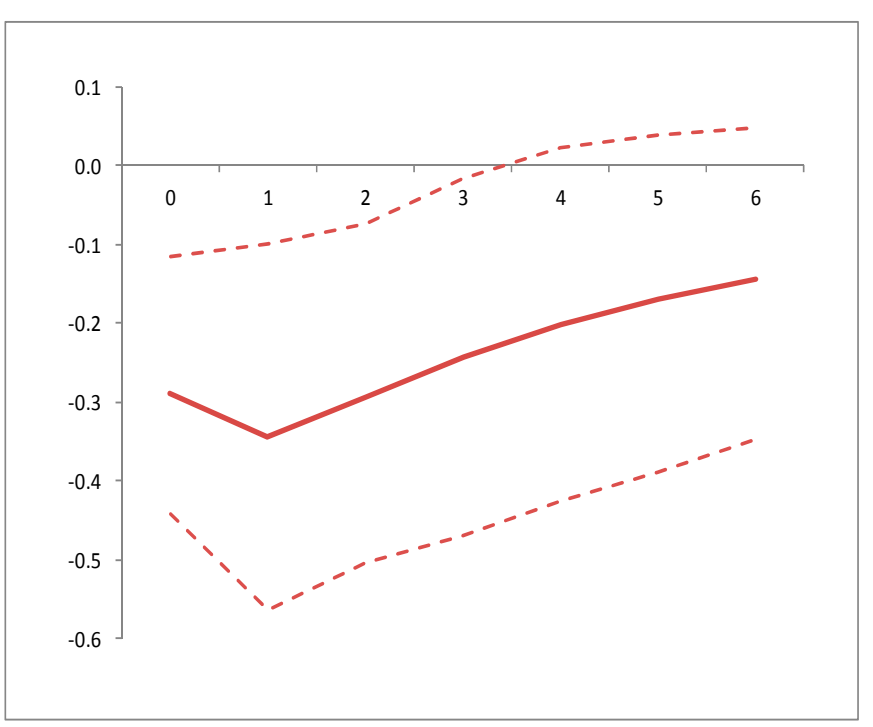




\section{CONCLUSION}

This paper has analyzed the relationship between fiscal policy and the current account. The paper's contribution consists of the breadth of its empirical investigation, in terms of both empirical techniques and country coverage. In a simple analysis of episodes of large adjustment in the current account and fiscal policy, we have found that the association between fiscal policy and the emergence or unwinding of large external imbalances is limited. Turning to econometric analysis, both panel regressions and panel VARs reveal a statistically significant association between fiscal policy and the current account. An improvement in the fiscal balance of 1 percent of GDP is found to improve the current account balance by $0.2-0.3$ percentage point of GDP upon impact, with the effects persisting for a few years. The association between fiscal policy and the current account has also been found to be at least as strong in emerging and low-income economies as in advanced economies, and significantly stronger in country-years where output is above potential than in cases where output is below potential. 


\section{Appendix I. Synthetic Summary of the Empirical Literature}

\begin{tabular}{|c|c|c|c|c|c|}
\hline Selected Papers & Sample and Methodology & Type of Fiscal Shock & $\begin{array}{l}\text { Effect on (Correlation With) the Current } \\
\text { Account }\end{array}$ & Effect on the Exchange Rate & Comments \\
\hline \multicolumn{6}{|c|}{ Papers using dynamic (VAR) specification or causality tests } \\
\hline This paper & $\begin{array}{l}124 \text { countries, annual data, } \\
1985-2007 \text {, panel VAR }\end{array}$ & $\begin{array}{l}1 \text { percent increase in } \\
\text { real government } \\
\text { consumption. }\end{array}$ & $\begin{array}{l}\text { The current account worsens by } 0.3 \\
\text { pct of GDP on impact. The effects } \\
\text { gradually peter out, becoming } \\
\text { insignificant after } 2-4 \text { years. }\end{array}$ & & $\begin{array}{l}\text { The impact is longer-lasting in emerging } \\
\text { countries than in advanced countries. }\end{array}$ \\
\hline Monacelli and Perotti (2007) & $\begin{array}{l}\text { US, UK, Canada and } \\
\text { Australia, quarterly data, } \\
\text { 1975-2006, VAR }\end{array}$ & $\begin{array}{l}1 \text { percent of GDP } \\
\text { increase in government } \\
\text { spending. }\end{array}$ & $\begin{array}{l}\text { The trade balance deteriorates sharply } \\
\text { (>0.6 pct. of GDP) in the UK (after } 5 \\
\text { quarters) and Australia (after } 3 \\
\text { quarters). It does not change } \\
\text { significantly for the US and Canada. }\end{array}$ & $\begin{array}{l}\text { By one year, the real effective } \\
\text { exchange rate depreciates by } 4 \\
\text { percent in the US and Australia, } \\
\text { and by } 2 \text { percent in the UK and } \\
\text { Canada. After } 2 \text { years, it starts } \\
\text { appreciating in Canada. }\end{array}$ & $\begin{array}{l}\text { The behavior of the trade balance } \\
\text { follows that of investment. When the } \\
\text { latter falls, the trade balance improves. }\end{array}$ \\
\hline Beetsma et al (2007) & $\begin{array}{l}14 \text { EU countries, annual } \\
\text { data, 1970-2004, panel VAR } \\
2 /\end{array}$ & $\begin{array}{l}1 \text { percent of GDP } \\
\text { increase in government } \\
\text { spending. }\end{array}$ & $\begin{array}{l}\text { The trade balance deteriorates by } 0.5 \\
\text { percent of GDP on impact and by } 0.8 \\
\text { percent of GDP after two years. }\end{array}$ & $\begin{array}{l}\text { The real effective exchange rate } \\
\text { appreciates, though with some } \\
\text { delay (after a year). }\end{array}$ & $\begin{array}{l}\text { The findings suggest that the main } \\
\text { source of movement of the trade } \\
\text { balance is an increase in output (and } \\
\text { not the exchange rate) following the } \\
\text { increase in public spending. }\end{array}$ \\
\hline Corsetti and Miller (2006) & $\begin{array}{l}\text { Australia, Canada, the UK } \\
\text { and the US, quarterly data, } \\
\text { 1980-2006. }\end{array}$ & $\begin{array}{l}1 \text { percent of GDP } \\
\text { increase in government } \\
\text { spending. }\end{array}$ & $\begin{array}{l}\text { The trade balance deteriorates by } 0.5 \\
\text { percent of GDP for the UK, } 0.17 \\
\text { percent of GDP for Canada. No } \\
\text { significant effect for the US and } \\
\text { Australia. }\end{array}$ & & $\begin{array}{l}\text { The impact reaches }-0.8 \text { percent of } \\
\text { GDP after } 4 \text { quarters for the UK but } \\
\text { vanishes after } 10 \text { quarters. For Canada, } \\
\text { the impact reaches } 1 \text { percent of GDP } \\
\text { after } 5 \text { quarters and is persistent for } \\
\text { extended period of time. }\end{array}$ \\
\hline Normandin (2006) & $\begin{array}{l}\text { G7 countries, quarterly } \\
\text { data, 1975-2001, causality } \\
\text { tests, VAR. }\end{array}$ & $\begin{array}{l}\text { One currency-unit tax } \\
\text { cut. }\end{array}$ & $\begin{array}{l}\text { No causality from the real CA (nominal } \\
\text { deflated by CPI) to real budget balance } \\
\text { (nominal deflated by CPI). VAR } \\
\text { estimates suggest that the effect on } \\
\text { the CA is not significantly different from } \\
\text { zero, except for France and Germany. }\end{array}$ & & \\
\hline Kim and Roubini (2004) & $\begin{array}{l}\text { US, quarterly data, 1973- } \\
2004 \text {, VAR }\end{array}$ & $\begin{array}{l}1 \text { percent of GDP } \\
\text { increase in government } \\
\text { primary deficit. }\end{array}$ & $\begin{array}{l}\text { The CA balance improves marginally } \\
\text { (less than } 0.1 \text { pct of GDP) for about a } \\
\text { year and the impact disappears } \\
\text { thereafter. }\end{array}$ & $\begin{array}{l}\text { Both the nominal and real } \\
\text { exchange rates depreciate } \\
\text { persistently }\end{array}$ & $\begin{array}{l}\text { The improvement in the CA comes from } \\
\text { the effects of higher savings and lower } \\
\text { investments as interest rates rise. }\end{array}$ \\
\hline
\end{tabular}




\section{Appendix I. Synthetic Summary of the Empirical Literature (continued)}

\begin{tabular}{|c|c|c|c|c|c|}
\hline Selected Papers & Sample and Methodology & Type of Fiscal Shock & $\begin{array}{l}\text { Effect on (Correlation With) the Current } \\
\text { Account }\end{array}$ & Effect on the Exchange Rate & Comments \\
\hline Normandin (1999) & $\begin{array}{l}\text { Us and Canada, quarterly } \\
\text { data, 1950-1992, VAR. }\end{array}$ & $\begin{array}{l}\text { Lump-sum tax cut that } \\
\text { increases the real } \\
\text { budget deficit (nominal } \\
\text { adjusted by GDP } \\
\text { deflator) by } 1 \text { unit. }\end{array}$ & $\begin{array}{l}\text { The (real) CA balance deteriorates by } \\
0.21-0.98 \text { units for the US, and by } 0.19- \\
0.67 \text { units for Canada. }\end{array}$ & & \\
\hline Khalid and Guan (1999) & $\begin{array}{l}5 \text { advanced economies } \\
\text { (1950-94) and } 5 \text { developing } \\
\text { countries (1955-93) annual } \\
\text { time series. Cointegration } \\
\text { and causality tests. } 3 /\end{array}$ & & $\begin{array}{l}\text { No cointegration (long-run relation) } \\
\text { between the CA and budget balance in } \\
\text { advanced economies, but evidence } \\
\text { does not reject such a relationship in } \\
\text { developing countries. For most of the } \\
\text { countries, evidence suggest a causal } \\
\text { relationship. }\end{array}$ & & $\begin{array}{l}\text { UK and Australia (no causality in either } \\
\text { direction). US, France, Egypt, and } \\
\text { Mexico (causality from the budget } \\
\text { balance to the CA balance). Canada, } \\
\text { and India (causality in both directions). }\end{array}$ \\
\hline Enders and Lee (1990) & $\begin{array}{l}\text { US, quarterly data, 1947-87, } \\
\text { VAR. }\end{array}$ & $\begin{array}{l}\text { Increase in real } \\
\text { government spending } \\
\text { (nominal adjusted for } \\
\text { inflation) by one unit; } \\
\text { increase in (real) } \\
\text { government debt. }\end{array}$ & $\begin{array}{l}\text { The (real) trade balance is not affected } \\
\text { on impact, but worsens it by } 0.002 \\
\text { units after } 8-10 \text { quarters; }\end{array}$ & $\begin{array}{l}\text { The nominal exchange rate is } \\
\text { initially volatile but depreciates } \\
\text { after } 9-16 \text { quarters. }\end{array}$ & \\
\hline \multicolumn{6}{|c|}{ Papers using single equations or panel regressions } \\
\hline This paper & $\begin{array}{l}124 \text { countries, annual data, } \\
\text { 1985-2007, panel } \\
\text { regressions. }\end{array}$ & $\begin{array}{l}1 \text { percent of GDP } \\
\text { increase in government } \\
\text { budget balance. }\end{array}$ & $\begin{array}{l}\text { The CA balance improves by about } 0.3 \\
\text { percent of GDP. }\end{array}$ & & $\begin{array}{l}\text { The improvement is stronger for } \\
\text { emerging countries than for advanced } \\
\text { ones. The improvement is smaller when } \\
\text { one excludes oil exporters. The } \\
\text { improvement is also larger when GDP } \\
\text { is above potential than when it is below } \\
\text { potential. }\end{array}$ \\
\hline Abiad, Leigh, and Mody (2009) & $\begin{array}{l}135 \text { countries, 1975-2004, } \\
5 \text {-year averages, random } \\
\text { effects generalized least } \\
\text { squares (with clustered } \\
\text { standard errors), panel } \\
\text { regressions. }\end{array}$ & $\begin{array}{l}1 \text { percent of GDP } \\
\text { increase in the } \\
\text { contemporaneous } \\
\text { budget balance (in } \\
\text { percent of GDP) }\end{array}$ & $\begin{array}{l}\text { The current account improves by about } \\
0.3 \text { percent of GDP in the full sample } \\
\text { regression. The coefficient becomes } \\
\text { negative/insignificant in regressions } \\
\text { with regional sub-samples of mostly } \\
\text { advanced and emerging economies. }\end{array}$ & & $\begin{array}{l}\text { Use additional controls the impact of } \\
\text { age dependency, net foreign assets-to- } \\
\text { GDP and financial integration. }\end{array}$ \\
\hline IMF (2008) & $\begin{array}{l}48 \text { countries, annual data, } \\
1980-2004, \text { panel } \\
\text { cointegration } 1 /\end{array}$ & $\begin{array}{l}1 \text { percent of GDP } \\
\text { increase in government } \\
\text { consumption. }\end{array}$ & & $\begin{array}{l}\text { The equilibrium real exchange } \\
\text { rate appreciates by } 2.5 \text { to } 3 \\
\text { percent. }\end{array}$ & $\begin{array}{l}\text { The equilibrium real exchange rate } \\
\text { could be significantly different from the } \\
\text { actual real exchange rate } \\
\text { (misalignment) }\end{array}$ \\
\hline
\end{tabular}




\section{Appendix I. Synthetic Summary of the Empirical Literature (continued)}

\begin{tabular}{|c|c|c|c|c|c|}
\hline Selected Papers & Sample and Methodology & Type of Fiscal Shock & $\begin{array}{l}\text { Effect on (Correlation With) the Current } \\
\text { Account }\end{array}$ & Effect on the Exchange Rate & Comments \\
\hline Bussière and Fratzscher (2005) & $\begin{array}{l}\text { G7 and } 21 \text { OECD countries, } \\
\text { annual data, } 1960-2003, \\
\text { panel and country-specific } \\
\text { time series regressions. }\end{array}$ & $\begin{array}{l}1 \text { percent of GDP } \\
\text { increase in the } \\
\text { cyclically-adjusted } \\
\text { primary budget } \\
\text { balance. }\end{array}$ & $\begin{array}{l}\text { No significant effect for the G7 panel } \\
\text { and country regressions. Small and } \\
\text { marginally significant increase ( } 0.07 \\
\text { pct of GDP) on the on CA for the group } \\
\text { of OECD countries. }\end{array}$ & & $\begin{array}{l}\text { Productivity seems to play a more } \\
\text { significant role. A } 1 \text { percent increase in } \\
\text { country-specific productivity decreases } \\
\text { the CA balance by } 0.15 \text { pct of GDP. }\end{array}$ \\
\hline Kennedy and Slok (2005) & $\begin{array}{l}14 \text { OECD countries, annual } \\
\text { data, 1982-2003, panel } \\
\text { regressions }\end{array}$ & $\begin{array}{l}1 \text { percent of GDP } \\
\text { increase in government } \\
\text { budget balance. }\end{array}$ & $\begin{array}{l}\text { The CA balance improves by about } 0.3 \\
\text { pct of GDP, once indicators of } \\
\text { structural policy are included. }\end{array}$ & & $\begin{array}{l}\text { The REER only has a marginal effect } \\
\text { on the CA. Indicators of structural } \\
\text { policies capture changes in product } \\
\text { market regulations, changes in stock } \\
\text { market capitalization, FDI } \\
\text { restrictiveness, employment protection } \\
\text { legislation, changes in structural } \\
\text { unemployment, and changes in trend } \\
\text { participation rate. }\end{array}$ \\
\hline Mohammadi (2004) & $\begin{array}{l}63 \text { countries ( } 20 \text { advanced } \\
\text { and } 43 \text { developing), annual } \\
\text { data, 1975-98, panel } \\
\text { regressions. }\end{array}$ & $\begin{array}{l}1 \text { percent of GDP } \\
\text { increase in government } \\
\text { spending. }\end{array}$ & $\begin{array}{l}\text { If the spending is tax-financed, the CA } \\
\text { balance worsens by } 0.16-0.29 \text { percent } \\
\text { of GDP ( } 0.23-0.32 \text { percent of GDP for } \\
\text { developing countries, and } 0.00-0.26 \text { for } \\
\text { advanced countries). If the spending is } \\
\text { bond-financed, the CA balance } \\
\text { worsens by } 0.45-0.72 \text { percent of GDP } \\
\text { (0.55-0.81 percent of GDP for } \\
\text { developing countries, and } 0.22-0.50 \text { for } \\
\text { advanced countries). }\end{array}$ & & $\begin{array}{l}\text { An improvement in the budget balance } \\
\text { by } 1 \text { percent of GDP improves the CA } \\
\text { by } 0.30-43 \text { percent of GDP }(0.33-49 \\
\text { percent of GDP for developing } \\
\text { countries, and } 0.21-0.24 \text { percent of } \\
\text { GDP). }\end{array}$ \\
\hline Piersanti (2000) & $\begin{array}{l}17 \text { OECD countries, annual } \\
\text { data, } 1970-1997 \text { panel and } \\
\text { country-specific time series } \\
\text { regressions }\end{array}$ & $\begin{array}{l}1 \text { percent of GDP } \\
\text { increase in expected } \\
\text { future government } \\
\text { budget balance. }\end{array}$ & $\begin{array}{l}\text { The CA balance improves for most } \\
\text { countries. The improvement varies from } \\
\text { about } 0.02 \text { pct of GDP to about } 0.32 \\
\text { pct of GDP }\end{array}$ & & $\begin{array}{l}\text { Within the sample period, actual budget } \\
\text { balances are assumed to be the best } \\
\text { market estimates of the expected future } \\
\text { government balance. }\end{array}$ \\
\hline Chinn and Prasad (2000) & $\begin{array}{l}18 \text { advanced and } 71 \\
\text { developing countries, annual } \\
\text { data, 1971-95, cross- } \\
\text { section, Panel. }\end{array}$ & $\begin{array}{l}1 \text { percent of GDP } \\
\text { increase in } \\
\text { government budget } \\
\text { balance. }\end{array}$ & $\begin{array}{l}\text { The CA balance improves by } 0.25-0.46 \\
\text { percent of GDP in the cross-section } \\
\text { regressions. The CA balance improves } \\
\text { in the range } 0.26-0.39 \text { pct of GDP. }\end{array}$ & & $\begin{array}{l}\text { Panel regression suggest that the effect } \\
\text { of the government balance is not } \\
\text { statistically significant for advanced } \\
\text { countries. Both panel and cross-section } \\
\text { regressions suggest that the impact of } \\
\text { the budget balance on the CA balance } \\
\text { is larger in developing countries than in } \\
\text { advanced ones. }\end{array}$ \\
\hline
\end{tabular}




\section{Appendix I. Synthetic Summary of the Empirical Literature (continued)}

\begin{tabular}{|c|c|c|c|c|c|}
\hline Selected Papers & Sample and Methodology & Type of Fiscal Shock & $\begin{array}{l}\text { Effect on (Correlation With) the Current } \\
\text { Account }\end{array}$ & Effect on the Exchange Rate & Comments \\
\hline Dewald and Ulan (1990) & $\begin{array}{l}\text { US, annual data, 1961-85, } \\
\text { single equations. }\end{array}$ & $\begin{array}{l}1 \text { percent of GDP } \\
\text { increase in government } \\
\text { budget deficit. }\end{array}$ & $\begin{array}{l}\text { The increase in the government budget } \\
\text { deficit is associated with an increase of } \\
\text { the CA deficit of } 0.61 \text { percent of GDP. }\end{array}$ & & $\begin{array}{l}\text { Same as Roubini (1988) for the US. The } \\
\text { coefficient is much smaller when } \\
\text { alternative specifications or other } \\
\text { measures of the fiscal stance are used. }\end{array}$ \\
\hline Miller and Russek (1989) & $\begin{array}{l}\text { US, quarterly data, 1946- } \\
1971,1971-87, \text { causality } \\
\text { tests, OLS and } \\
\text { cointegration. }\end{array}$ & $\begin{array}{l}1 \text { percent of GDP } \\
\text { increase in government } \\
\text { budget deficit. }\end{array}$ & $\begin{array}{l}\text { Causality tests suggest that fiscal } \\
\text { deficits generally lead trade deficits, } \\
\text { and support for reverse causation is not } \\
\text { overwhelming. The increase in the } \\
\text { government budget deficit is associated } \\
\text { with an increase of the CA deficit that } \\
\text { varies from } 0.20 \text { to } 0.45 \text { percent of GDP } \\
\text { depending on model specification. }\end{array}$ & & $N$ \\
\hline Roubini (1988) & $\begin{array}{l}18 \text { OECD countries, annual } \\
\text { data, from } 1961-85 \text { to } 1971- \\
85 \text {, single equations. }\end{array}$ & $\begin{array}{l}1 \text { percent of GDP } \\
\text { increase in government } \\
\text { budget deficit. }\end{array}$ & $\begin{array}{l}\text { The increase in the government budget } \\
\text { deficit is associated with an increase of } \\
\text { the CA deficit of } 0.14-0.61 \text { percent of } \\
\text { GDP depending on the country. }\end{array}$ & & \\
\hline Bernheim (1988) & $\begin{array}{l}\text { US, UK, Canada, Germany, } \\
\text { Mexico, annual data, 1960- } \\
84 \text {, single equations. }\end{array}$ & $\begin{array}{l}1 \text { percent of GDP } \\
\text { increase in government } \\
\text { budget surplus. }\end{array}$ & $\begin{array}{l}\text { The increase in the government budget } \\
\text { surplus is associated with an increase } \\
\text { of the CA surplus of } 0.3 \text { percent of } \\
\text { GDP for the US, Canada, the UK, } 0.2 \\
\text { percent of GDP for Germany, and } 0.7 \\
\text { for Mexico. }\end{array}$ & & \\
\hline Summers (1986) & $\begin{array}{l}\text { US, annual data, 1950- } \\
1985 \text {, single equations }\end{array}$ & $\begin{array}{l}1 \text { US dollar increase in } \\
\text { budget deficit }\end{array}$ & $\begin{array}{l}\text { The current account balance worsens } \\
\text { by } 0.25 \text { dollars. }\end{array}$ & & $\begin{array}{l}\text { Private savings improve by about } 0.06 \\
\text { dollars and net foreign investment by } \\
\text { about } 0.32 \text { dollars, leading to a decline } \\
\text { in the current of about } 0.25 \text { dollars. }\end{array}$ \\
\hline
\end{tabular}

1/ See Exchange Rate Assessments: CGER Methodologies, Occasional Paper 261, International Monetary Fund, Washington DC, 2008.

2/ Austria, Belgium, Denmark, Finland, France, Ireland, Italy, Germany, Greece, the Netherlands, Portugal, Spain, Sweden, and the UK.

3/ Advanced economies: US, UK, France, Canada, Australia. Developing countries: India, Indonesia, Pakistan, Mexico, and Egypt. 


\section{Appendix II: Fiscal Policy, the Current Account and the Real Exchange Rate: A Review of Theory}

Given the difficulty of predicting short-run nominal exchange rate movements, studies of exchange rate determination have typically focused on identifying variables that drive "real" exchange rates over the medium to long-run (Froot and Rogoff, 1995). Fiscal policy emerges as a natural protagonist in these studies due to its potentially significant impact on the size and composition of aggregate demand both of which are directly relevant for exchange rate movements (Corsetti and Muller, 2006). Moreover, fiscal and current account balances are bound by the well-known saving-investment identity-current account balance equals (public plus private) saving minus investment. The "twin deficits" debate is usually framed around this identity (see Truman, 2004 or Chinn, 2005 for recent non-technical summaries).

The possible causal channels running from fiscal policy to the current account and real exchange rate operate through economic agents: choices about intratemporal and intertemporal trade.

Intratemporal trade (relative price changes): this channel works through the compositional effects of fiscal policy on aggregate demand-i.e. whether a fiscal policy change raises the demand for domestic (or nontradable) goods relative to foreign (or tradable) goods - and the impact thereof on the real exchange rate (the relative price of home to foreign goods) and the trade balance. Thus, increases in government spending (tax or debt-financed) if skewed towards home (or non-tradable goods), appreciates the real exchange rate and worsens the trade balance. The channel is highlighted well by both the Mundell-Fleming (1960) and dependent economy models (a la Salter, 1959).

Intertemporal responses: this channel abstracts from differentiated goods and real exchange rate misalignments, focusing instead on the intertemporal response of private agents to a given fiscal policy action in a one-commodity world. Now, a debt-financed fiscal impetus that seeks to worsen the trade balance, induces forward-looking agents to impute to their permanent incomes the offsetting future tax increases consistent with intertemporal government solvency. Hence, labor supply rises while private consumption falls, both effects seeking to improve the trade balance and pushing the economy towards a Ricardian outcome. The channel is articulated well in Obstfeld and Rogoff (1996) and Frenkel and Razin (1996).

More recent advances in theory-exemplified by dynamic general equilibrium/new open economy models such as Backus et al (1994), Obstfeld and Rogoff (1995), Monacelli and Perotti (2007) and Kumhof and Laxton (2009) — have permitted an integration of both the static and intertemporal dimensions, and an explicit treatment of imperfect competition, nominal rigidities and policy reaction functions, to help uncover more complex transmission channels between fiscal and external sector aggregates.

The Mundell-Fleming model highlights well the workings of the relative price channel for a small open economy, as well as the importance of variables such as financial openness, currency structure of public debt, and monetary/exchange rate regime in determining the current account impact of fiscal policy changes. An expansionary fiscal shock raises the demand for home goods and money, inducing a real appreciation (either through higher interest rates and arbitrage capital inflows, or a rise in domestic prices) that crowds out net exports. However, if the capital account 
is relatively closed, a more enduring increase in interest rates results, crowding out investment, raising private savings, and thus softening the impact on the currency and trade balance. Similarly, with a large initial foreign currency debt commitment, a currency depreciation (not appreciation) is required to induce the negative wealth effect necessary to restore money market equilibrium.

The model also reveals the centrality of exchange rate regime, degree of price flexibility and risk premia in determining whether fiscal policy can reduce external imbalances. For example, starting from a position of full employment and trade deficit, a fiscal contraction can restore external balance by inducing a nominal exchange rate depreciation (that makes foreign goods more expensive) and boosting net exports. With a currency peg, however, a "real" depreciation is required, which is possible only if prices are downwardly flexible. Moreover, the fiscal contraction can lower endogenous risk premia (due to improved perceptions of fiscal solvency and encourage more capital inflows, leading to inflationary pressures and a further worsening of the current account (expansionary fiscal contractions).

The intuition of the Mundell-Fleming model-which cannot distinguish between the real exchange rate (an endogenous variable) and the terms of trade-does not naturally extend to small developing economies facing exogenous terms of trade. As Montiel (1999) and Edwards (1989) note, dependent economy models can usefully delineate the real exchange rate as the relative price of tradable to nontradables from the exogenously given terms of trade. The impact of fiscal policy on the trade balance can be best understood through an experiment involving a shift in government spending from tradables to non-tradables. Two offsetting effects obtain: a reduction in government tradables consumption that improves the trade balance; and an induced real appreciation (higher relative price of nontradables) that switches private consumption [production] toward [away from] tradables and worsens the trade balance. An additional layer of complexity is added if government spending is assumed to exert direct supply-side effects through either crowding out/in of private capital accumulation or raising/lowering of productivity (Adam and Bevan, 2005; Leigh, 2008).

In contrast to the two relative price approaches described above, the intertemporal approaches take a longer-run view, abstracting from deviations from purchasing power parity (and thus real exchange rate misalignments), and casting the current account simply as the excess of current domestic production over current domestic consumption of a single homogenous worldwide good (Frenkel and Razin, 1996). A key assumption in these forward-looking micro-founded models is that agents take into account future events in their current decisions (agents are Ricardian or near-Ricardian).

An increase in debt-financed government spending, in this framework, works through the "future" to induce a higher saving and work effort response from private agents "today": agents can foresee that the government must raise future taxes in order to offset the current fiscal deficit and ensure intertemporal solvency; these tax increases reduce the present value of future income (human wealth) and thus induce lower private consumption and higher labor supply in the present. The latter also raises the marginal product of capital, crowding in private investment. The current account deteriorates as long as the private saving increase (net of higher investment) does not offset the decline in public savings (Baxter, 1995). 
A related class of models, cast mostly in the overlapping generations framework (i.e. nonRicardian agents), locates the current account response to a current debt-financed fiscal expansion in the context of anticipated "closure rules.” Kawai and Maccini (1995) show that, under the knowledge of a binding intertemporal solvency constraint on the government, agents with finite lives would consume more today (leading to a larger current account deficit) in response to a debt financed fiscal expansion if they anticipate its future closure through higher taxes. This on-impact "twin deficits" result is stronger when future taxes are expected to fall on consumption, as an intertemporal substitution of consumption occurs towards the present. By contrast, the current account could improve if agents anticipate that the government will resort to inflationary finance in the future: the real value of money holdings falls, so that given a fixed initial bondholding, real wealth falls and hence consumption declines. In the same vein, Abbas (forthcoming) shows how the anticipation of future debt relief can render a foreign debt-financed fiscal expansion a pro-borrowing policy and exacerbate current account deficits.

New open economy models developed recently in advanced country contexts incorporate both the intertemporal and intratemporal dimensions as well as other advanced features such as imperfect competition, sticky prices and policy reaction functions, in an attempt to reconcile empirical puzzles found in the data: private consumption rising, real exchange depreciating (despite the trade balancing worsening) in response to a positive government spending shock.

Perotti and Monacelli (2007) argue that private consumption could indeed rise in response to a government spending shock if agents needed to consume more to compensate for the misery of working harder and agents were unwilling to tilt consumption towards the future (small intertemporal elasticity of substitution). The real exchange rate depreciation is explained through international risk-sharing in complete financial markets: i.e. the marginal rate of substitution between the home and foreign country private consumption must be mirrored by the real exchange rate. Thus, a rise in current home private consumption (relative to the rest of the world) implies a real depreciation of the home currency. Finally, the worsening of the trade balance obtains if consumption of foreign goods is relatively insensitive to the real depreciation (intratemporal elasticity of substitution between home and foreign goods is low). Ravn et al (2007) offer a different set of explanation for the same result: higher demand following the government spending shock induces firms to lower their markups (real depreciation) in a bid to capture market share; consumption rises and the trade balance worsens.

Thus, unlike the simple Mundell-Fleming model, these new open economy models permit the real exchange rate to depreciate and the trade balance to worsen at the same time. The models also highlight the role of interaction variables such as intertemporal and intratemporal elasticities, trade and financial openness, and government size, which can alter the expected effects of fiscal policy.

Insights of the IMF GIMF model (Kumhof and Laxton, 2009) on the effects of fiscal consolidation are also worth noting: a permanent cut in government consumption weakens aggregate demand (and output) on impact, lowers inflation relative to target, and induces a monetary policy reaction in the form of an interest rate cut. This depreciates the real exchange rate and boosts domestic absorption, partially offsetting the contractionary effects of the fiscal consolidation. Net exports and the current account improve, and so do net foreign assets and domestic savings. The decline in public debt and the associated reduction in interest payments 
(due to reduction in risk premium) permit a reduction in taxes, which raises output above the initial steady state over the medium to long-run (Leigh, 2008).

Other channels binding the fiscal and current account balances can occur through current or anticipated tax policy changes - especially the mix of capital and labor income/consumption taxes on the one hand, and of consumption and social security contributions on the other-which can affect capital inflows, investment, work effort and consumption, all of which are important for the external sector (OECD 2007; Beck and Coskuner, 2007; Tanzi and Zee, 2000; Alworth and Arachi, 2007). 


\section{REFERENCES}

Abiad, Abdul, Daniel Leigh, and Ashoka Mody, 2009, “Financial Integration, Capital Mobility, and Income Convergence,” Economic Policy, Vol. 24, No. 58, pp. 241-305.

Adam, Christopher, and David Bevan, 2005, "Fiscal Deficits and Growth in Developing Countries,” Journal of Public Economics, Vol. 89, No. 4.

Alworth, Julian, and G. Arachi, 2007, “Taxation policy in EMU.” Paper presented at the EMU at 10 years Conference held in Brussels on November 26-27.

Arellano, Manuel, and Olympia Bover, 1995, “Another Look at the Instrumental Variable Estimation of Error Component Models,” Journal of Econometrics, Vol. 68, pp. 29-51.

Backus, David, Patrick J. Kehoe, and Finn E. Kydland, 1994, “Dynamics of the Trade Balance and the Terms of Trade: The J-Curve?” American Economic Review, Vol. 84, No. 1, pp. 84-103.

Baxter, Marianne, 1995, “International Trade and Business Cycles,” In: G. M. Grossmann and K. Rogoff, Editors, Handbook of International Economics, Vol. 3, Amsterdam, North-Holland, pp. 1801-1864.

Beck, Stacie, and Cagay Coskuner, 2007, “Tax Effects on the Real Exchange Rate,” Review of International Economics, Vol. 15, No. 5, pp. 854-868 (November).

Bussière, Matthieu, Marcel Fratzscher, and Gernot J. Müller, 2005, “Productivity Shocks, Budget Deficits, and the Current Account," European Central Bank Working Paper, No. 509.

Beetsma, Roel, Massimo Giuliodori, and Franc Klaassen, 2007, “The Effects of Public Spending Shocks on Trade Balances and Budget Deficits in the European Union,” Journal of the European Economic Association, April-May 2008, Vol. 6, No. 2-3, pp. 414-23.

Bernheim, Douglas B.,1988, “Budget Deficits and the Balance of Trade,” Tax policy and the Economy, Vol. 2, 1988, pp. 1-31.

Chinn, Menzie D., 2005, “Getting Serious About the Twin Deficits,” Council on Foreign Relations Special Report.

Chinn, Menzie D., and Eswar S. Prasad, 2003, "Medium-Term Determinants of Current Accounts in Industrial and Developing Countries: An Empirical Exploration," Journal of International Economics, Vol. 59, pp. 47-76.

Corsetti, Giancarlo, and Gernot J. Müller, 2006, "Budget Deficits and Current Accounts: Openness and Fiscal Persistence,” Economic Policy, Vol. 21 (October), No. 48, pp. 597-638. 
Dewald, William G., and Michael Ulan, 1990, “The Twin-Deficit Illusion,” Cato Journal, Vol. 9 (Winter), No. 3, pp. 689-707.

Edwards, Sebastian, 1989, Real Exchange Rates, Devaluation, and Adjustment: Exchange Rate Policy in Developing Countries (Cambridge, Massachusetts: MIT Press).

Enders, Walter, and Bong-Soo Lee, 1990, “Current Account and Budget Deficits: Twins or Distant Cousins?” Review of Economics and Statistics, Vol. 72, No. 3, pp. 373-81.

Feyrer, James, and Jay Shambaugh, 2009, “Global Savings and Global Investment: The Transmission of Identified Fiscal Shocks,” Dartmouth College and NBER (Cambridge, Massachusetts: National Bureau of Economic Research).

Frenkel, Jacob A., and Assaf Razin, 1996, Fiscal Policies and Growth in the World Economy (Cambridge, Massachusetts: MIT Press).

Froot, Kenneth A., and Kenneth Rogoff, 1995, "Perspectives on PPP and Long-Run Exchange Rates,” NBER Working Paper No. 4952 (Cambridge, Massachusetts: National Bureau of Economic Research).

International Monetary Fund, 2008, Exchange Rate Assessments: CGER Methodologies, IMF Occasional Paper No. 261 (Washington: International Monetary Fund).

Kawai, Masahiro, and Louis J. Maccini, 1995, “Twin Deficits versus Unpleasant Fiscal Arithmetic in a Small Open Economy,” Journal of Money, Credit, and Banking, Vol. 27, pp. 639-58.

Kennedy, Mike, and Torsten Sløk, 2005, "Structural Policy Reforms and External Imbalances,” OECD Economics Department Working Paper, No. 415 (Paris: Organization for Economic Cooperation and Development).

Khalid, Ahmen M., and Teo W. Guan, 1999, "Causality Tests of Budget and Current Account Deficits: Cross-Country Comparisons,” Empirical Economics, Vol. 24, 1999, pp. 389-402.

Kim, Soyoung, and Nouriel Roubini, 2008, “Twin Deficit and Twin Divergence? Fiscal Policy, Current Account, and Real Exchange Rate in the U.S.," Journal of Economic Literature, Vol. 74, pp. 362-383.

Kumhof, Michael, and Douglas Laxton, 2009, “Fiscal Deficits and Current Account Deficits,” IMF Working Paper No. 09/237 (Washington: International Monetary Fund).

Lane, Philip R., and Gian M. Milesi-Ferretti, 2006, “The External Wealth of Nations Mark II: Revised and Extended Estimates of Foreign Assets and Liabilities, 1970-2004,” IMF Working Paper No. 06/69 (Washington: International Monetary Fund). 
Lane, Philip R., 2010, “External Imbalances and Fiscal Policy,” IIIS Discussion Paper No. 314, Institute for International Integration Studies, Trinity College Dublin and CEPR.

Leigh, Daniel, 2008, “Achieving a Soft Landing: The Role of Fiscal Policy,” IMF Working Paper No. 08/60 (Washington: International Monetary Fund).

Miller, Stephen M., and Frank S. Russek, 1989, “Are the Twin Deficits Really Related?” Contemporary Policy Issues, Vol. 7 (October).

Mohammadi, Hassan, 2004, "Budget Deficits and the Current Account Balance: New Evidence from Panel Data,” Journal of Economics and Finance, Vol. 28, No. 1, (Spring), pp. 39-45.

Monacelli, Tommaso, and Roberto Perotti, 2007, "Fiscal Policy, the Trade Balance, and the Real Exchange Rate: Implications for International Risk Sharing,” Università Bocconi, Milan, Italy.

Montiel, Peter J., 1999, In: Lawrence Hinkle and Peter J. Montiel, Editors, The Long-Run Equilibrium Real Exchange Rate: Conceptual Issues and Empirical Research, pp. 219-263 (Oxford: Oxford University Press).

Mundell, Robert A., 1960, “The Monetary Dynamics of International Adjustment Under Fixed and Flexbile Exchange Rates,” Quarterly Journal of Economics, Vol. 74 (May), No. 2, pp. 227-257.

Mundell, Robert A., 1960, “The Pure Theory of International Trade,” American Economic Review, Vol. 50 (March), pp. 67-110.

Normandin, Michel, 1999, “Budget Deficit Persistence and the Twin Deficits Hypothesis,” Journal of International Economics, Vol. 49, pp. 171-193.

Normandin, Michel, 2006, "Fiscal Policies, External Deficits, and Budget Deficits," Cahier de Recherche/Working Paper No. 06-32 (Montreal: CIRPÉE).

Obstfeld, Maurice, and Kenneth Rogoff, 1995, “Exchange Rate Dynamics: Redux”, Journal of Political Economy, Vol. 103, pp. 624-660.

Obstfeld, Maurice, and Kenneth Rogoff, 1996, Foundations of International Macroeconomics (Cambridge, Massachusetts: MIT Press).

OECD, 2007, “Consumption Taxes: the Way of the Future?” October Policy Brief (Paris: Organization for Economic Cooperation and Development).

Piersanti, Giovanni, 2000, “Current Account Dynamics and Expected Future Budget Deficits: Some International Evidence,” Journal of International Money and Finance, Vol. 19, pp. 255-271. 
Ravn, Morten O., Stephanie Schmitt-Grohe, and Martin Uribe, 2007, "Pricing to Habits and the Law of One Price,” American Economic Review, Papers and Proceedings, Vol. 97 (May), pp. 232-238.

Ravn, Morten O., Stephanie Schmitt-Grohe, and Martin Uribe, 2007, "Explaining the Effects of Government Spending Shocks on Consumption and the Real Exchange Rate” (Durham, North Carolina: Duke University).

Romer, Christina D., and David H. Romer, forthcoming, "The Macroeconomic Effects of Tax Changes: Estimates Based on a New Measure of Fiscal Shocks,” American Economic Review.

Roubini, Nouriel, 1988, "Current Account and Budget Deficits in an Intertemporal Model of Consumption and Taxation Smoothing. A Solution to the Feldstein-Horioka Puzzle?” NBER Working Paper, No. 2773.

Salter, Wilfred A., 1959, "Internal and External Balance: The Role of Price and Expenditure Effects,” Economic Record, Vol. 35, pp. 226-38.

Summers, Lawrence H., 1986, “Debt Problems and Macroeconomic Policies,” NBER Working Paper, No. 2061 (Cambridge, Massachusetts: National Bureau of Economic Research).

Truman, Edwin, 2004, “Budget and External Deficits: Same Family but Not Twins.” Prepared for the Federal Reserve Bank of Boston Annual Research Conference, June 14-16.

Tanzi, Vito, and Howell H. Zee, 2000, “Tax Policy for Emerging Markets - Developing Countries,” IMF Working Paper No. 00/35 (Washington: International Monetary Fund). 